WSRC-MS-2003-00170

Rev 0

\title{
Innovative Flash Control in Inertia Welding
}

By

\author{
P. S. Korinko and H. B. Peacock \\ Westinghouse Savannah River Company \\ Savannah River Site \\ Aiken, SC
}

A document prepared for the

DOE Contract No. DE-AC09-96SR18500

This paper was prepared in connection with work done under the above contract number with the U.S. Department of Energy. By acceptance of this paper, the publisher and/or recipient acknowledges the U.S. Government's right to retain a nonexclusive, royaltyfree license in and to any copyright covering this paper, along with the right to reproduce and to authorize others to reproduce all or part of the copyrighted paper. 
This document was prepared in conjunction with work accomplished under Contract No. DE-AC09-96SR18500 with the U. S. Department of Energy.

\section{DISCLAIMER}

This report was prepared as an account of work sponsored by an agency of the United States Government. Neither the United States Government nor any agency thereof, nor any of their employees, makes any warranty, express or implied, or assumes any legal liability or responsibility for the accuracy, completeness, or usefulness of any information, apparatus, product or process disclosed, or represents that its use would not infringe privately owned rights. Reference herein to any specific commercial product, process or service by trade name, trademark, manufacturer, or otherwise does not necessarily constitute or imply its endorsement, recommendation, or favoring by the United States Government or any agency thereof. The views and opinions of authors expressed herein do not necessarily state or reflect those of the United States Government or any agency thereof.

This report has been reproduced directly from the best available copy.

Available for sale to the public, in paper, from: U.S. Department of Commerce, National Technical Information Service, 5285 Port Royal Road, Springfield, VA 22161, phone: (800) 553-6847, fax: (703) 605-6900

email: orders@ntis.fedworld.gov

online ordering: http://www.ntis.gov/help/index.asp

Available electronically at http://www.osti.gov/bridge

Available for a processing fee to U.S. Department of Energy and its contractors, in paper, from: U.S. Department of Energy, Office of Scientific and Technical Information, P.O. Box 62, Oak Ridge, TN 37831-0062,

phone: (865)576-8401,

fax: (865)576-5728

email: $\underline{\text { reports@ adonis.osti.gov }}$ 


\section{Innovative Flash Control in Inertia Welding}

\author{
P. S. Korinko \\ Westinghouse Savannah River Company \\ Aiken, SC 29803
}

\author{
H. B. Peacock \\ Westinghouse Savannah River Company \\ Aiken, SC 29803
}

\begin{abstract}
Inertia welding is widely used to join cylindrically shaped objects such as disks and shafts in turbine engines, turbochargers, etc. Flash control in many of these applications is not critical because the excess material is on external surfaces and can readily be removed by machining. Internal flash on hollow vessels, however, may be difficult or impossible to remove and may be either controlled by the use of flash traps or the part can be used as welded. Both internal flash and flash traps reduce internal volume and the conditions are not always acceptable. To address this short-coming, several innovative methods have been tested to determine their effect on flash control in inertia welding of hollow vessels. The methods include introduction of high pressure inert gas and incorporation of an expendable mandrel to divert the flash. Both gas and internal mandrels appear promising methods for diverting flash.
\end{abstract}

Keywords: Inertia welding, flash control, mandrels, internal pressure

\section{BODY}

Inertia welding is a solid-state welding process. Fixing one piece and rotating the other to an appropriate speed joins the two rotationally symmetric components. The drive motor is disengaged and the parts are brought into contact at the programmed force. Frictional contact generates heat as the parts are brought together under load. When the upset force is applied, the metal is deformed and plastically flows both inward and outward for a tubular weld. ; This extruded metal is called the flash. There are options to deal with upset material remaining on the external surface of a part and include either using the part in the "as-welded" condition or removing the flash by machining. Internal surfaces of parts without ready access must be used as-welded or alternative methods to direct or control the flash must be implemented.
Conventional flash control uses "flash traps". These constructs are generally machined features that either deflect the metal flow or be of a size and geometry to fully capture the upset material. The knowledge to effectively implement flash traps has been developed over the years. The geometric requirements are well understood ${ }^{1}$.

The Savannah River Technology Center (SRTC) has determined that alternative methods to control flash should be investigated. These methods include the use of internal gas at high pressure and expendable mandrels. The preliminary testing and optimization of these techniques are the topic of this paper.

$\begin{array}{ll}\text { NOMENCLATURE } \\ \text { CD } & \text { Ceramic Disk } \\ \text { MR } & \text { Metal Ring } \\ \text { EDM } & \text { Electro-Discharge Machine } \\ \text { FEM } & \text { Finite Element Model } \\ \text { IW } & \text { Inertia Welding } \\ \text { RPM } & \text { Revolutions per minute } \\ \text { SS } & \text { Stainless Steel } \\ \text { SRTC } & \text { Savannah River Technology Center } \\ \text { Wk }^{2} & \text { Flywheel Mass }\end{array}$

\section{EXPERIMENTAL}

Type 304 stainless steel (SS) bar stock was machined into test components that simulate the geometry of an actual component. Sub-size components were not required since the actual components are of a reasonable size. The typical geometry for the weld samples is shown in Figure 1. Weld samples that were used in conjunction with pressurization contained pipe threads, while the internal mandrel samples were closed at both ends.

Review of the literature indicates that a weld energy of about $30,000 \mathrm{ft}-\mathrm{lbs}$ and a force of approximately $20,000 \mathrm{lbs}$ are required to successfully weld stainless steel ${ }^{2}$. Weld energy is 
related to equipment set-up parameters (flywheel inertia) and rotational speed by the following equation ${ }^{3}$.

$$
\text { Energy (Ft-Lbs) }=\mathrm{Wk}^{2} * \mathrm{RPM}^{2} / 5873 \text {. (eq. 1) }
$$

$\mathrm{Wk}^{2}$ is dependent on the mass and diameter of the headstock and flywheel assembly. Thus there are two variables that should be used for development, force and RPM, flywheel inertia is part of the machine. For the work reported, a flywheel with a $\mathrm{Wk}^{2}$ of 8.5 was used. The rotational speed and calculated energy are shown in Table 1.

Table 1. Welding conditions used with a flywheel having a Wk ${ }^{2}$ of 8.5

\begin{tabular}{|l|l|l|l|l|l|}
\hline $\begin{array}{l}\text { Weld } \\
\text { ID }\end{array}$ & $\begin{array}{l}\text { RPM } \\
(1000)\end{array}$ & $\begin{array}{l}\text { Energy } \\
(\text { Ft-Lb) }\end{array}$ & $\begin{array}{l}\text { Force } \\
(\mathrm{lb})\end{array}$ & $\begin{array}{l}\text { Gas Pres } \\
(\mathrm{psi}) \\
\text { Mandrel }\end{array}$ & $\begin{array}{l}\text { Upset } \\
(\mathrm{in})\end{array}$ \\
\hline 1 & 5100 & 37,600 & 37,420 & None & 0.050 \\
\hline 2 & 5,000 & 36,200 & 37,420 & 350 & 0.053 \\
\hline \multirow{2}{*}{$3 *$} & 5500 & 43,800 & 11,000 & 2500 & 0.016 \\
\cline { 2 - 5 } & 4000 & 23,200 & 37,000 & & 0.038 \\
\hline 4 & 6775 & 66,400 & 20,000 & CD & 0.013 \\
\hline \multirow{2}{*}{$5 *$} & 6275 & 57,000 & 4,000 & \multirow{2}{*}{ MR } & 0.013 \\
\cline { 2 - 4 } & 4440 & 28,500 & 20,000 & & \\
\hline
\end{tabular}

Notes: CD denotes ceramic disk. MR denotes metal ring. * refers to two step weld.

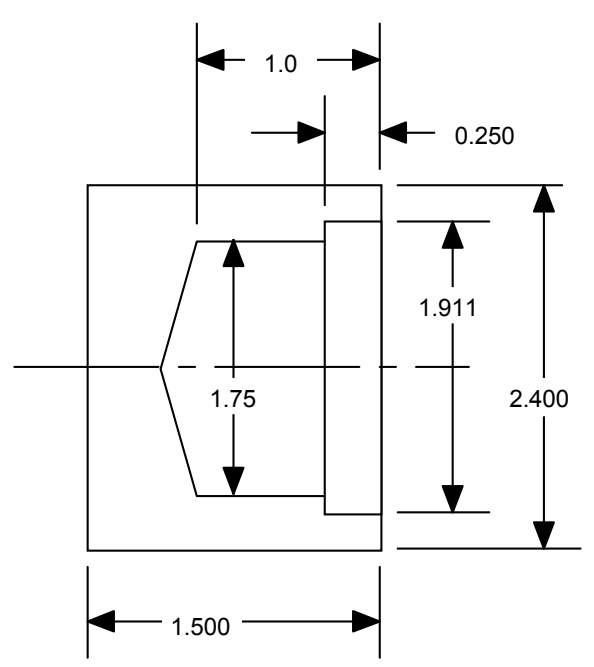

Figure 1. Weld sample geometry, note "step" 0.25 " from open end.

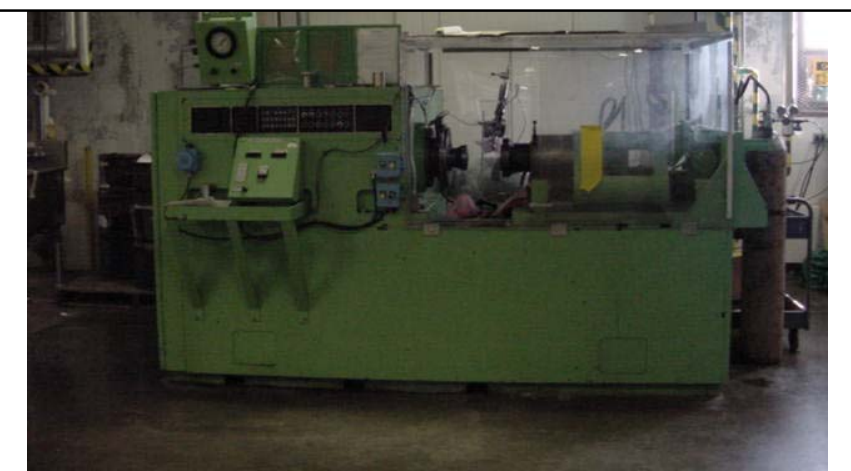

Figure 2. Inertia welder used for development work.
The weld upset was targeted at 0.02 inch, which is significantly less than that typically used in industry. The general rule of thumb is to have the upset twice the wall thickness for tube welds. For this application the associated

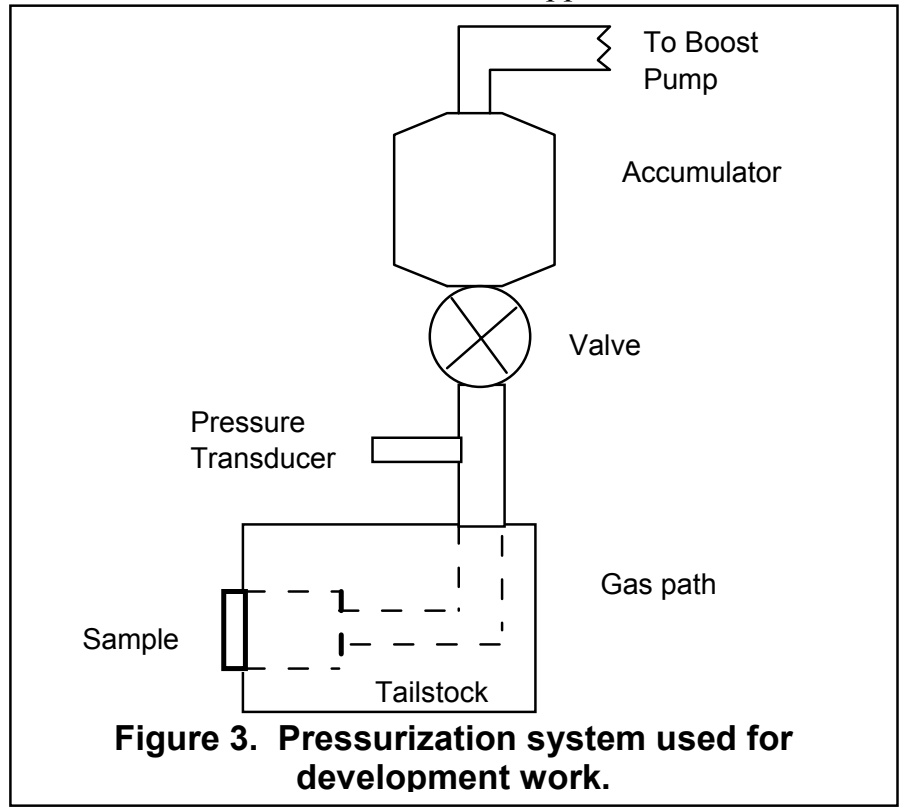

flash volume associated with a large upset is unacceptable. Tests were conducted at a variety of conditions, several are listed in Table 1.

A Caterpillar manufactured model 100 inertia welder was used to perform the work. The welder was modified to increase the ram load capacity in the headstock from a maximum of 30,000 to $37,000 \mathrm{lbs}$ of force. A photograph of the inertia welder is shown in Figure 2. This welder rotates the headstock, which moves forward to apply the upset force. All welds were made by having the distance between the part approximately 0.06 inches.

The weld sequence is that the head stock moves to the starting position and rotates to the desired RPM; the drive mechanism disengages and the weld force is applied and when rotation stops, the parts are held for a few seconds during which the weld cools. The collets are released automatically. The entire weld process takes about 1 minute.

Argon gas was introduced either continuously or "instantaneously" during weld tests. For continuous gas flow, samples achieved a maximum pressure of about 1600 psi while the instantaneous pressure method achieved a limit of 2500 psi. A schematic of the pressurization system is shown in Figure 3. Gas injection is controlled manually shortly after "red heat" was visually detected.

The internal mandrels were machined to within approximately 0.003 inch of the weld sample internal diameter and inserted into the stationary tailstock pieces. The mandrels used the step on the tailstock part as a locating feature. Glass, ceramic, and metal rings and disks were evaluated in this study.

\section{Results}

A cross-section of a typical weld made with neither internal pressure nor a mandrel is shown in Figure 4 . The internal surface exhibits some oxidation and a uniform internal and external flash. The axial upset was approximately 0.05 
inch. These results are typical for welding parameters used for these hollow, pipe-like, samples.

To better control the internal upset, pressurized welding was initiated using a high flow regulator and a simple dump valve. These welds were made such that the argon gas flowed through the system prior to welding. The pressure loss was minimized by keeping the part gap as small as possible, however, the pressure at the weld was about $50 \%$ of the set pressure. Using the same weld parameters as were used for the baseline weld at 400 and 800 psi internal pressure resulted in welds with similar amounts of axially upset, but the amount of internal flash was reduced by about 0.01 inch. However, the

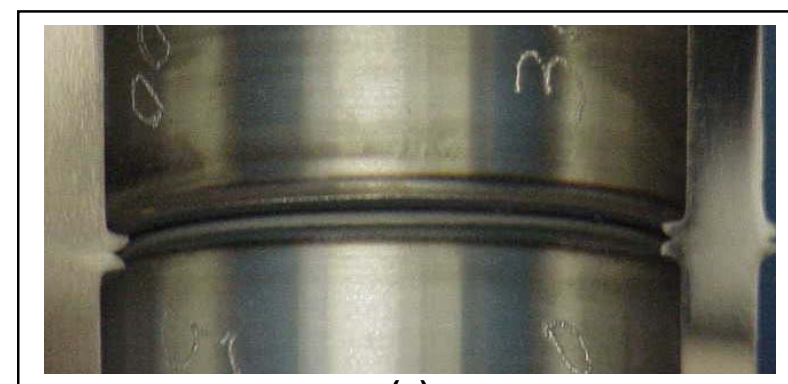

(a)

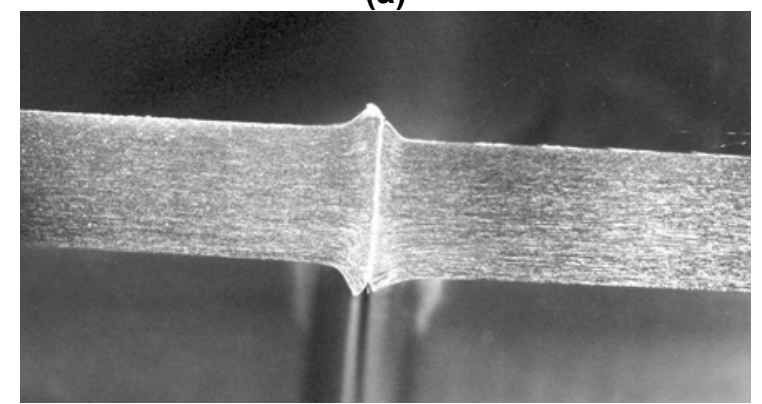

(b)

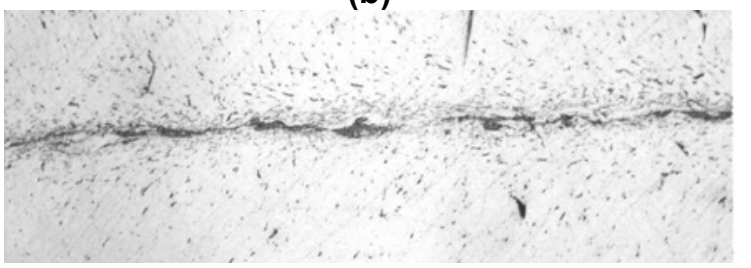

(c)

Figure 4. Typical weld condition (\#1) using nominal weld conditions and no pressure (a) macrophotograph of internal surface (b) low magnification micrograph of joint (c) higher magnification of interface.

most encouraging aspect of these welds was the cleanliness of the internal surface and the absence of heat tint discoloration. The typical internal surface of the higher-pressure welded sample is shown in Figure 5, which shows no oxidation banding like that seen in the conventionally welded samples. The sample was metallographically prepared and etched with the weld interface shown in Figure $5 b$. This interface is reasonably clean. Some apparent melting and grain refinement at the interface are evident.

\section{Finite Element Calculations}

A simple finite element model (FEM) was developed to validate the methodology of using internal pressure to control

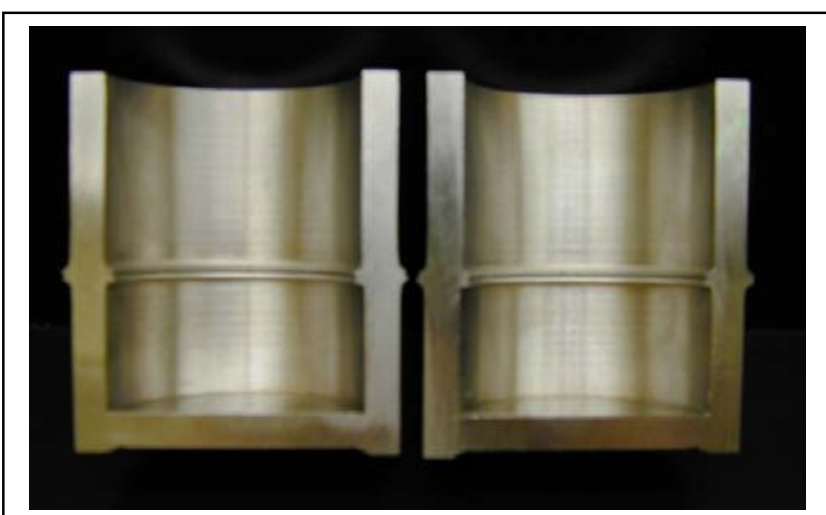

(a)

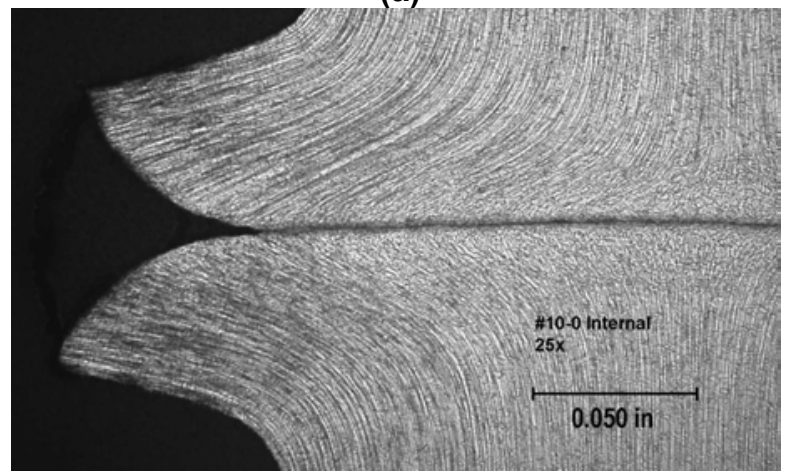

(b)

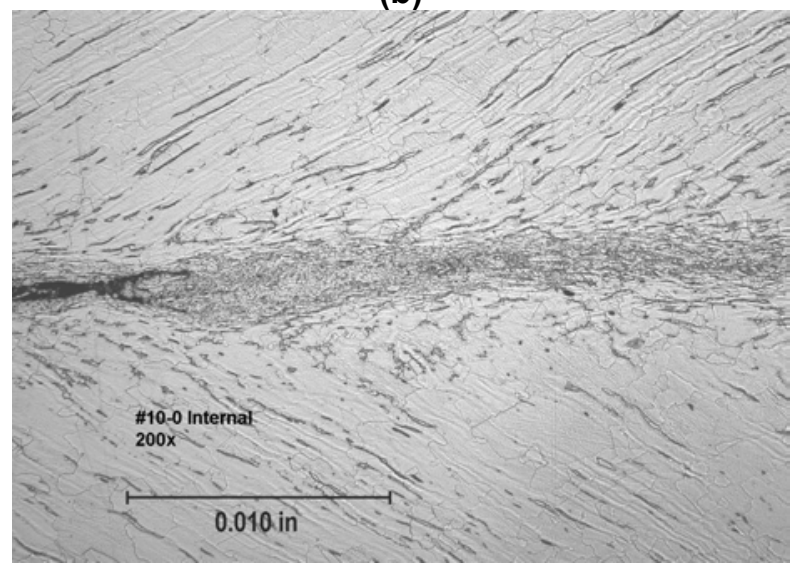

(c)

Figure 5. Weld \#2 low gas pressure, (a) Internal surface of sample (b) micrograph of weld interface at the internal surface and (c) higher magnification of internal surface near the root of the notch showing flow lines.

the flash. The model indicated that it was possible to decrease the flash, however, low upset welds may be required. The FEM output for two conditions is shown in Figure 6. It can be seen that small internal extrusion can be achieved at high internal pressure and a balanced axial force. The calculated axial upset and internal and external flash are listed in Table 2.

\section{Two-Step Weld with Internal Pressure}

The welding process was modified to use a two step weld. This method was intended to allow for preheating prior to the introduction of gas pressure. The gas impinges on softened material to force it outward instead of inward thus reducing the 


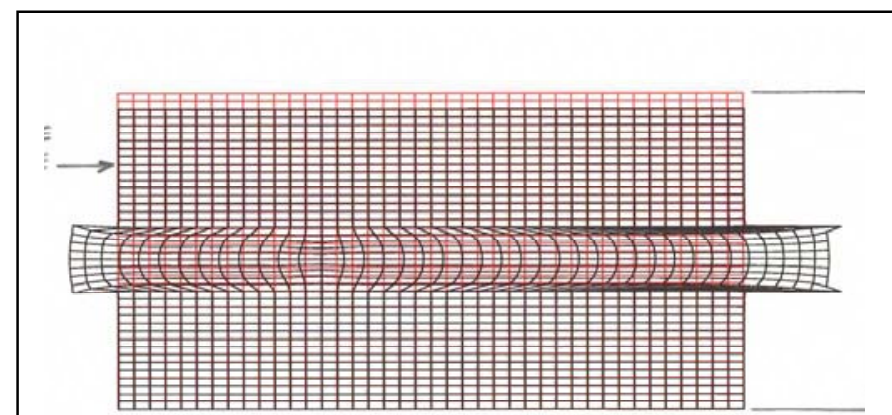

(a)

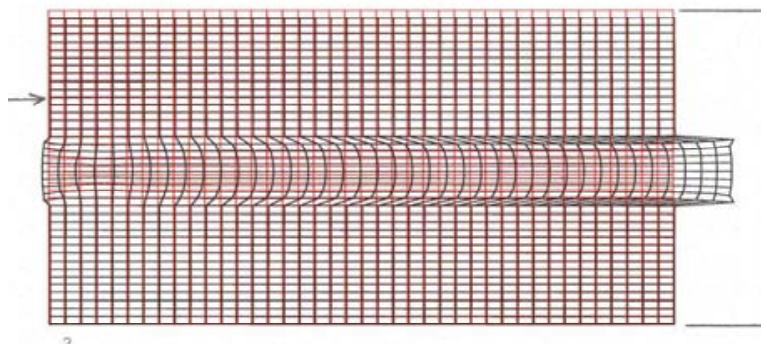

(b)

\section{Figure 6. FEM output for (a) low and (b) high internal pressures.}

internal flash. Welding force was determined based on the FE model and previous tests. The applied axial force must overcome the force exerted by the internal gas pressure. In order to decease the time needed to reach the final pressure an accumulator was incorporated into the gas train as indicated in Figure 3.

Table 2. Calculated resutls from the FEM.

\begin{tabular}{|l|l|l|l|l|}
\hline $\begin{array}{l}\text { Force } \\
(\mathrm{lb})\end{array}$ & $\begin{array}{l}\text { Int. Pres. } \\
\text { (psi) }\end{array}$ & $\begin{array}{l}\text { Upset } \\
\text { (in) }\end{array}$ & $\begin{array}{l}\text { Int. Flash } \\
\text { (in) }\end{array}$ & $\begin{array}{l}\text { Ext. Flash } \\
\text { (in) }\end{array}$ \\
\hline 10,000 & 2000 & 0.006 & 0.019 & 0.034 \\
\hline 13,600 & 2000 & 0.013 & 0.047 & 0.055 \\
\hline 15,800 & 4000 & 0.003 & 0.002 & 0.024 \\
\hline 18,100 & 4000 & 0.008 & 0.02 & 0.050 \\
\hline \multicolumn{5}{|l}{} \\
\hline
\end{tabular}

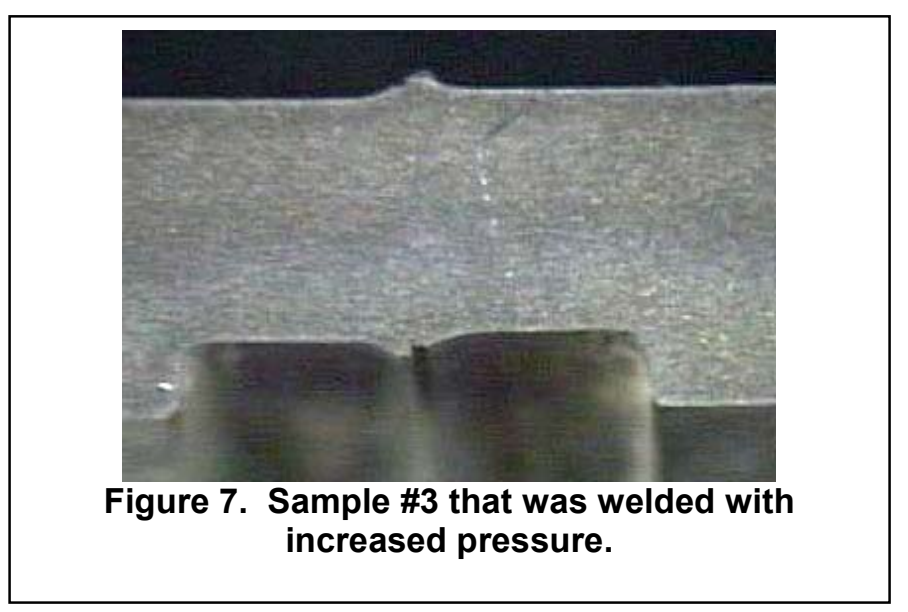

Several samples were welded using this pressurization system. Initially samples were welded at forces just large enough to overcome the back force from the internal gas pressure. The welds formed using these parameters were unacceptable having minimal bonding, less than $50 \%$ across the interface. The upset was near zero, which is not unexpected based on prior tests. The internal surfaces were oxidized, much like the samples welded without internal gas pressure. The internal surface oxidized since the region of the weld was heated in laboratory air rather than under argon as occurred for the continuously flowing gas. A typical sample that was welded with increased pressure is shown in Fig. 7. The beneficial effects of internal gas pressure are not patently obvious. The bond-line is not visible in the EDM cut surface. The amount of upset is approximately 0.016 inch as indicated in Table 1. Additional tests and continuing efforts will be reported in subsequent articles.

\section{Flash Trap / Mandrels}

An integral flash strap, machined step, or other feature, on the internal surface often is used to contain internal flash. The incorporation of these features must be anticipated during the preliminary development stages to ensure that adequate material is provided in forgings or other raw materials used for the component. For instance, additional stock on the internal diameter from 0.05 to 0.150 inch may be necessary to divert flash and to prevent bending in stainless steel joints of the size being developed. This internal flash trap may affect critical internal dimensions and internal volume.

Flash traps can be complex features with rings and grooves in addition to undercuts and various radii. These features may be needed depending on whether the flash trap's purpose is contain and control flash or if it's to change flow direction and avoid open notches on the internal surface.

To minimize the size of forgings and to reduce machining complexity, a novel approach to integral flash traps has been tested internal mandrels. In this concept, the mandrels are of a different material that may be removed without adversely affecting the weld quality.

As a first approach, sacrificial glass, ceramic and metal rings as well as solid discs were tried. Both glass and ceramic rings lacked adequate impact strength to withstand the weld process. A machinable ceramic disk was subsequently tried. It withstood the welding forces but lacked adequate strength to preclude deformation during welding. A cross-section of the weld sample with the ceramic disc mandrel is shown in Fig. 8. It is apparent from this photograph that the upset material is not symmetric as is typically observed for normal inertia welds. There appears to be more upset on the head stock piece, to the right in Fig. 8. In addition, the disk lacked the strength to avoid being deformed by the weld material. It is apparent that a stiffer and stronger material is needed for this internal mandrel concept.

A ferritic stainless steel mandrel was also evaluated. The concept behind using this material is that it would be less corrosion resistant than the austenitic material. Thus, it may be possible to chemically etch the mandrel out of the vessel using an appropriate chemical. A macrophotograph of the weld sample made with the ferritic SS mandrel is shown in Fig. 9a. The ring, which was originally placed flush against the tailstock piece, has migrated towards the head-stock piece, i.e., to 
the right. There is also some evidence of frictional heating on the ring since it exhibits some discoloration on both the macro scale as well as on the microscale as shown in Fig. 9b. The mandrel apparently bonded to the flash as shown in the micrograph presented in Fig. 9c

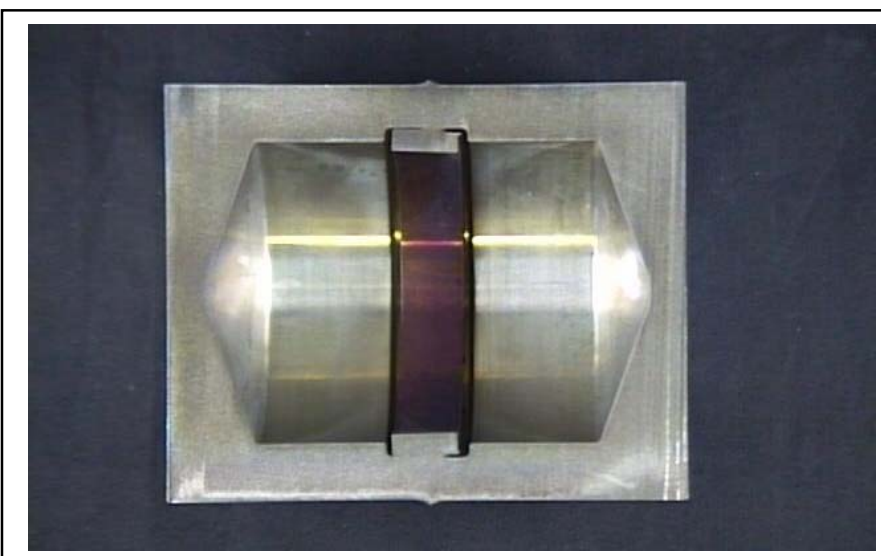

(a)

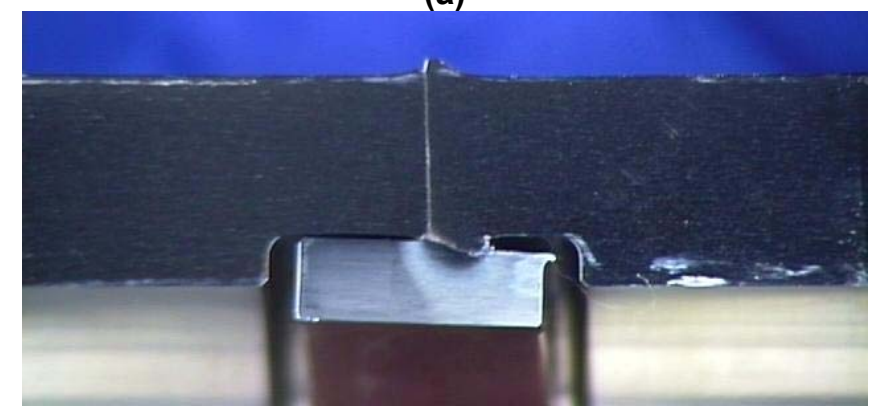

(b)

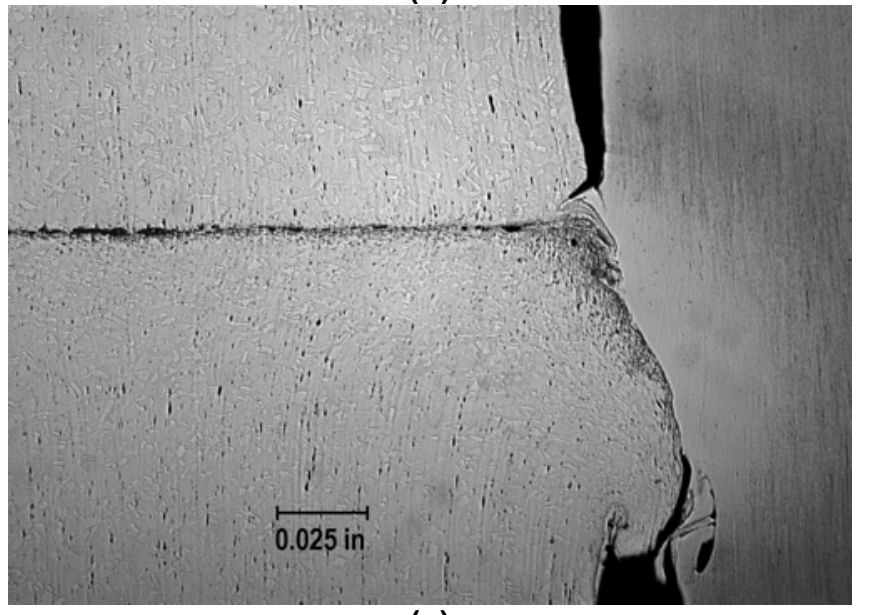

(c)

Figure 9. Sample 5 welded with metal ring (a) macrophotograph (b) microphotograph showing interaction with metal ring (c) higher magnification of the ring vessel interface.

\section{DISCUSSION}

Two innovative methods of controlling flash in hollow inertia welds are under development. These techniques are advanced methods of controlling flash in inertia welds. The tests reported in this document indicate that both pressure and mandrels have demonstrated utility for modifying the flash. Additional optimization of the techniques is required for introduction of either method into a production setting.

\section{SUMMARY}

Preliminary work discussed in this paper reveals that it may be possible to control flash in inertia welds by using high pressure gas or expendable mandrels as alternatives to conventional flash traps. Additional testing and concepty development is needed.

\section{ACKNOWLEDGMENTS}

The authors would like to thank G. Chapman for operating the welder, cutting samples, and assisting in other ways. We would also like to thank Z. Nelson, C. Foreman, V. Timmerman, J. Wilderman, and T. Curtis for metallographic sample preparation and N. Gupta for developing the FEM model. We would like acknowledge the guidance and support of K. Hicken, M. Balmforth, and C. Pretzel of Sandia National Laboratories. This document was prepared in connection with work done at Westinghouse Savannah River Company under Contract No. DE-AC09-89SR18035 and DE-AC09-96SR18500 with the U.S. Department of Energy.

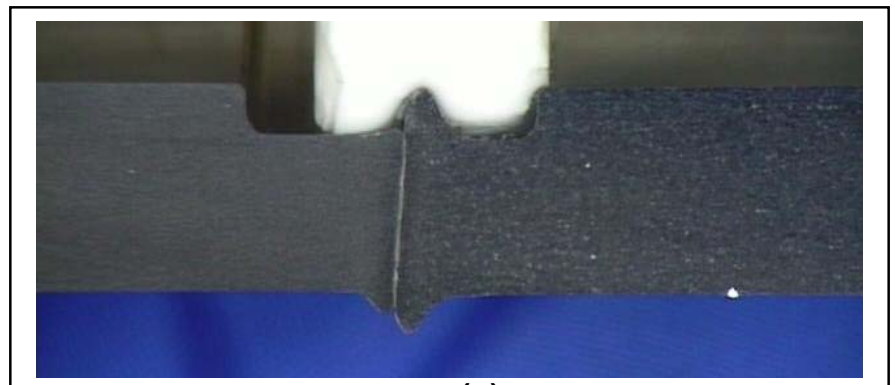

(a)

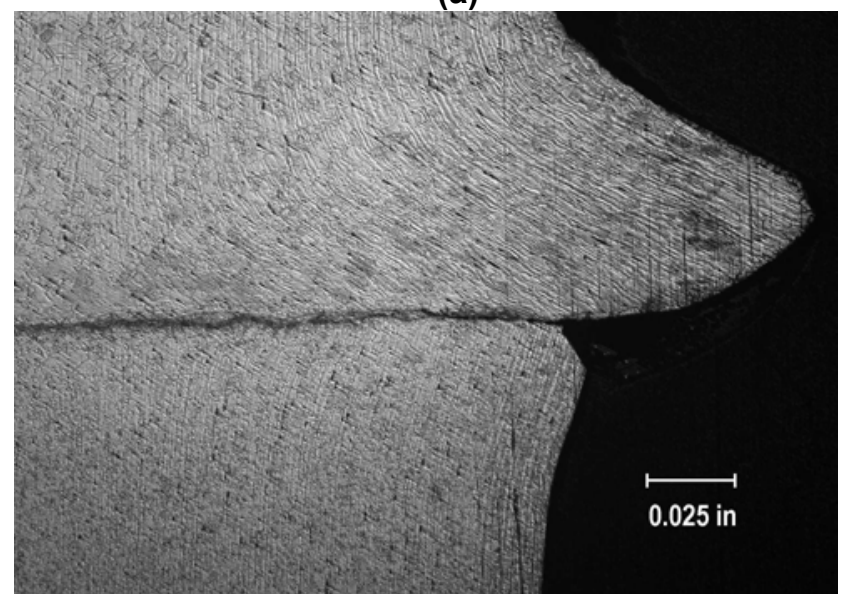

(b)

Figure 8. Sample \#4 welded with machinable ceramic disk mandrel (a) macrophotograph (b) microphotograph showing flash and disk interaction.

\section{REFERENCES}

1. H. B. Peacock, Method and device for frictional welding, U.S. Patent No. 5,154,340, Oct. 1992.

2. A. S. Wadleigh, Inertia Welding Industrial Energy Saver, National Defense Magazine, July-August 1978.

3. Inertia Welding Application Principles, Interface Welding. 